\title{
Child mental health care in the context of the Family Health Strategy: an evaluative study
}

\author{
Cuidado em saúde mental infantil no contexto da Estratégia \\ da Saúde da Família: estudo avaliativo \\ Cuidado en salud mental infantil en el contexto de la Estrategia \\ de Salud de la Familia: estudio evaluativo
}

\author{
Juliana de Carvalho \\ Maria de Lourdes Custódio Duarte ${ }^{b}$ \\ Cecília Helena Glanznerc
}

\section{How to cite this article:}

Carvalho J, Duarte MLC, Glanzner

CH. Child mental health care in the context of the Family Health Strategy: an evaluative study. Rev Gaúcha Enferm. 2020;41(esp):e20190113. doi: https://doi.org/10.1590/19831447.2020.20190113
Secretaria da Saúde do Estado do Rio Grande do Sul. Coordenadoria de Saúde. Porto Alegre, Rio Grande do Sul, Brasil.

b Universidade Federal do Rio Grande do Sul (UFRGS), Escola de Enfermagem, Departamento de Assistência e Orientação Profissional. Porto Alegre, Rio Grande do Sul, Brasil.

'Universidade Federal do Rio Grande do Sul (UFRGS), Escola de Enfermagem, Departamento de Enfermagem Médico-Cirúrgica. Porto Alegre, Rio Grande do Sul, Brasil.

\begin{abstract}
Objective: To evaluate child's mental health care in the context of the Family Health Strategy, from the professionals' perspective. Methods: A qualitative case study type, using the Fourth Generation Assessment as a methodological reference. Fourteen professionals from two teams of the Family Health Strategy of Porto Alegre/RS were the participants. Data collection extended from May to August 2018, and consisted of observations and interviews through the dialectical hermeneutic circle, and of analysis through the Constant Comparative Method.
\end{abstract}

Results: The analytical category emerged of Mental Health Care for Children related to home visit, care network, advice, team meeting and space in the medical agenda.

Conclusions: The results show that the FHS is an important psychosocial care space and that, at the same time, presents weaknesses in cross-sectorial work and needs support from the mental health services network to accompanying children and families.

Keywords: Mental health. Family Health Strategy. Psychosocial support systems.

\section{RESUMO}

Objetivo: Avaliar o cuidado em saúde mental à criança no contexto da Estratégia de Saúde da Família - ESF, a partir da perspectiva dos profissionais.

Métodos: Estudo qualitativo, tipo estudo de caso, utilizou-se a Avaliação de Quarta Geração como referencial metodológico. Participaram 14 profissionais de duas equipes da Estratégia de Saúde da Família do município de Porto Alegre/RS. A coleta de dados ocorreu entre maio e agosto de 2018, consistiu em observação e entrevista através do círculo hermenêutico dialético, e análise através do Método Comparativo Constante.

Resultados: Emergiu a categoria analítica Cuidado de Saúde Mental destinado à Criança relacionada visita domiciliar, rede de cuidados, matriciamento, reunião de equipe e espaço na agenda médica.

Conclusões: Os resultados demonstram que a ESF se constitui em um importante espaço de cuidado psicossocial, ao mesmo tempo encontra fragilidades no trabalho intersetorial e necessita de apoio da rede de serviços de saúde mental para o acompanhamento de crianças e famílias.

Palavras-chave: Saúde mental. Estratégia Saúde da Família. Sistemas de apoio psicossocial.

\section{RESUMEN}

Objetivo: Evaluar la atención de salud mental a niños en el contexto de la Estrategia de Salud de la Familia (ESF), desde la perspectiva de los profesionales.

Métodos: Estudio cualitativo, del tipo estudio de casos, en el que se utilizó la Evaluación de Cuarta Generación como referencial metodológico. Catorce profesionales de dos equipos de la Estrategia de Salud de la Familia de Porto Alegre/RS participaron en el estudio. La recolección de datos se registró entre mayo y agosto de 2018, consistió en observaciones y entrevistas a través del círculo hermenéutico dialéctico, y en análisis a través del Método Comparativo Constante.

Resultados: Surgió la categoría analítica de Atención de salud mental a niños en relación con: visita domiciliaria, red de atención, asesoramiento, reunión de equipo y espacio en la agenda médica.

Conclusiones: Los resultados demuestran que la ESF es un importante espacio de atención psicosocial, al mismo tiempo que presenta debilidades en el trabajo intersectorial y necesita el apoyo de la red de servicios de salud mental para acompañar a los niños y a las familias.

Palabras clave: Salud mental. Estrategia Salud de la Familia. Sistemas de apoyo psicosocial. 


\section{口INTRODUCTION}

The process of Psychiatric Reform in Brazil caused changes in the mental health care model, redirecting it to care centered on the subject and outside the asylums. Based on the public policy on mental health, new services and articulation of care points were instituted in order to expand access to psychosocial care, entitled Psychosocial Care Network (PSCN) ${ }^{(1)}$.

The PSCN has different components and services, such as: Primary Health Care, Specialized Psychosocial Care, Psychosocial Care Centers (PSCCs) in its different modalities, Urgency and Emergency Services, Transient Residential Care, Hospital Care with beds in a general hospital, de-institutionalization devices and Psychosocial Rehabilitation Strategy ${ }^{(2-3)}$. In addition, recently established in the PSCN, mental health outpatient clinics and beds in psychiatric hospitals (PHs) $)^{(2-3)}$.

Given the specificities of childhood and the demand recognition for mental disorders in children, the Child Psychosocial Care Center (CPSCC) is the specific device and ordering of the PSCN ${ }^{(4)}$. Implemented in municipalities or regions with more than one hundred and fifty thousand inhabitants, the CPSCC is intended for the care of children and adolescents with severe and persistent mental disorders, including those resulting from the use of psychoactive substances ${ }^{(3)}$.

It is estimated that $10.8 \%$ to $12.7 \%$ of the child population suffers from some mental health problem, the most common being related to anxiety, behavior problems, hyperactivity and depression ${ }^{(5)}$. These complaints can reach the health professionals through parents or guardians, as well as through through the school.

However, the existence of specialized services, such as the CPSCC, does not contemplate most municipalities in Brazil. Thus, it is in Primary Care (PC), through the Family Health Strategy (FHS), that the main form of access to the different demands related to child mental health occurs. After all, the FHS reaches a coverage of over $60 \%$ of the Brazilian population with over 40,000 set up teams ${ }^{(6)}$.

In Brazil, the FHS is the main modality of $P C^{(6)}$. The health interventions in this mode of care should be based on therapeutic attitudes that privilege care, reception and bond between professional and user, which, in the psychosocial perspective, care is continued and includes families from a geographically delimited area.

The FHS is an important form of access to health and to develop activities that promote children's mental health and well-being, by meeting the different demands of child population in need of mental health care. They provide longitudinal follow-up, promoting comprehensive health care and contextualized with determinants factors of child's quality of life and health, in relation to their community ${ }^{(7)}$. After all, the FHS has in its scope of actions mental health care, based on the principles of psychosocial care.

However, the approach of mental health and PC actions is still a challenge ${ }^{(8)}$. Within the scope of the child population it is even more recent to recognize that children and adolescents have mental health problems and that these problems can be treated and cared for ${ }^{(4,7)}$.

Therefore, it is relevant to implement studies that evaluate mental health care to child from the perspective of the FHS as a service in health network. Studies have recognized the importance of approximating mental health to children in the context of $\mathrm{PC}(4,7-8)$, although little discussed focusing on the assessment of children's mental health care, which can enrich and broaden discussions in the academic field, as well as contributing to health services practices. In this context of the PSCN's services, the assessment emerges as an important instrument that can recognize advances in child mental health care.

Thus, an evaluation proposal that recognizes the need for advances and that has been enhancing the transformation in mental health care model is the Fourth Generation Evaluation $(\mathrm{FGE})^{(9)}$. The FGE is a qualitative assessment model in which the claims, concerns and questions of those involved in the process serve as information implemented in the research ${ }^{(9)}$.

In this scenario, the FGE is inserted as an alternative to assess health services, considering that the results can contribute to the improvement of children's care, through an assessment with an approach that considers subjective aspects of the evaluation process.

It is believed that the FHS is a fertile field to develop activities that promote child mental health care. However, mental health care for these children still needs further study and investigation. Thus, the question is: What is the evaluation of the FHS professionals about mental health care to child in this context? Therefore, the objective was to evaluate mental health care to the child in the context of the FHS, from the professionals' perspective.

Then, an evaluative study may be a subsidy to qualify the child mental health care in the FHS, considering that currently child mental health care in the context of the PC needs more visibility in the country, in the health system and in the recognition of the actions taken by professionals at this level of care; viewing the lack of scientific and academic information to support technical assistance on the subject. 


\section{DETHODOLOGY}

This is an evaluative research, with a qualitative approach in which an assessment of mental health care for children in the FHS was conducted, based on the theoretical and methodological framework of the FGE ${ }^{(9)}$.

The FGE proposes a responsive constructivist assessment. The term responsive is used to denote a differential in the assessment, delimited through an interactive and negotiating process that develops a critical process among the interest group. The term constructivist, also called interpretative or hermeneutic, refers to the evaluative methodology used(9).

The study was developed in two teams of the Family Health Strategy in the city of Porto Alegre/RS with FHS professionals that constituted the interest group. The term "interest group" refers to organizations, groups or individuals that are potentially victims or beneficiaries of the evaluation process, made up of individuals with common characteristics, who have some interest in the performance, product or impact of the object of evaluation, and are in any way involved or affected by the service and by any consequences of the evaluation process ${ }^{(9)}$.

The information was collected from May to August 2018 through observations and semi-structured interviews with the interest group. A total of 120 hours of field observations were recorded in a field diary.

Fourteen interviews were conducted in the FHS facilities; the interviews were identified with the initial letter $E$ (from entrevistas in Portuguese), followed by the order in which they appeared in the interview. For the purposes of this study, the following inclusion criteria were considered: being a professional of the health team hired by the Municipal Institute of the Family Health Strategy (Instituto Municipal da Estratégia de Saúde da Família, IMESF) and having at least six months of experience in the health service, as this period comprises the minimum time of activities in the community and knowledge of the context under study. The following was considered as the exclusion criterion: being on vacation or leave during the data collection period.

The interviews were conducted with the application of the Dialectic Hermeneutic Circle, hermeneutic because it has an interpretative character, and dialectic because it implies a comparison and opposition of points of view, aiming at an elaborated synthesis, seeking consensus whenever possible(9).

Thus, initially two guiding questions were applied: "Tell me about child mental health care in the FHS" and "Tell me about how the demands of child care arrive in the FHS", beginning the Dialectic Hermeneutic Circle. The central themes, concepts, ideas, values, problems and questions proposed by the initial respondent R1 were analyzed by the researcher; this construction was designated as C1. Afterwards, the following respondent (R2) was asked to answer the same guiding questions and, afterwards, the C1 construct was introduced, and R2 was invited to comment on it. The process was repeated until all the participants of the interest group who agreed to participate were interviewed. It is noteworthy that the information analysis occurred concurrently with data collection, based on the Constant Comparative Method, which allows for the analysis to be performed concurrently ${ }^{(10)}$.

After the interviews, the negotiation stage was performed with the participants, at which time the unfolded constructions that emerged from the interest group were presented. The final stage of the analysis consisted of grouping the constructions into an analytical category called: Mental Health Care for the child.

The study was approved by the Research Ethics Committee of the UFRGS under No.2,595,152 and of the Municipal Health Secretariat of Porto Alegre under No.2,720,722. The study met the ethical precepts of research ${ }^{(11)}$. The participants were the professionals who agreed to participate in the research; they were informed about the objectives of the research and those who accepted signed the Free and Informed Consent Form. The interviews were recorded and then transcribed literally, ensuring the veracity of the information.

\section{RESULTS AND DISCUSSION}

The study participants that constituted the interest group were professionals of the FHS teams, predominantly female, with a mean age of 40 years old and working on average six years and five months in the health service, enough time to understand the dynamics of the service, knowing the weaknesses and potentialities in the community.

The themes that emerged from the Fourth Generation assessment formed the analytical category for Mental Health Care for the Child related to home visits, care network, matrix, team meeting, and medical calendar space.

Thus, a form of care evidenced by the interest group in the evaluation process was home visits by the Community Health Agents (CHAs), a means of identifying children with mental health care needs in the territory of the FHS. The CHAs are in contact with the children's home and family context, providing the identification of those who may require mental health monitoring. 
When we enter the house, the mother speaks or the guardian speaks, and the CHA has to have a look to check what is happening with the child and then bring it to the team meeting. (E7)

The CHA detects at the household, in the same home and brings to the service, for the doctor and the team that directs to whom this child has to be directed. (E1)

Child mental health care detected at home through Home Visits (HVs) can be a strategic resource in the scope of substitutive mental health services, such as the FHS. The $\mathrm{HV}$ becomes a strategy to humanize care and to unleash bonds among users, staff and family; this tool is permeated by light technologies such as communication, welcoming and bonding, dialog and listening ${ }^{(12)}$.

The HV is a working tool mainly for CHAs in the evaluated context that helps to identify risk situations and allows guidance to families and communities, as well as to identify cases and situations that will be shared with other health team members ${ }^{(12)}$. The $H V$, as a mental health care measure, enables interaction, promotes bonding and facilitates comprehensive care for children and families, making the residence a therapeutic space in childcare.

The activities carried out as a result of the Health at School Program (Programa de Saúde na Escola, PSE) were identified as a means of child mental health care and make up the care network. These activities carried out in community schools bring teachers closer to the health service, promoting timely access to psychosocial care.

Usually the teacher talks to the father, and we include the school in the follow-up, because the school is a fundamental part of the child's opinion. The child sometimes spends more time at school than at home. (E4)

When the CHAs go to school to do this monitoring (PSE), the teachers, the principals bring up some case of some child. (E5)

This ease of dialog between education and health is positive for care in the context under study, since the child often uses these sectors simultaneously. Specifically in the case of child mental health, this often involves the sectors of health, education, as well as social welfare, justice and rights ${ }^{(4)}$.

In the field of psychosocial care, the co-responsibility of care in the territory is enhanced with actions of the PSE, since in larger municipalities education and health are faced with communities of great territorial extension, with diversity in the profile of social vulnerability and population needs ${ }^{(13)}$.

The PSE aims to contribute to the integral formation of public education students with prevention, promotion and health care actions ${ }^{(13)}$. However, the interest group assessed that actions are far from achieving the objective of the program, as they are punctual and fail to offer expanded attention to mental health care.

We work with anthropometry, weight, height, visual acuity, guidance on health and often with teachers. (E1)

In mental health, I have not seen anything that is related to the PSE, it is more about guidance on dengue, louse, and tooth brushing. (E3)

Thus, effective shared work across sectors requires sensitive and committed workers. The resolution of child mental health issues should be rethought, requiring dialog among the territory services, overcoming referrals, without discussing cases among services in the PSCN(9). In addition, in the context of childcare, the opportunity to articulate mental health with the school space should be encouraged and consolidated through actions that integrate the FHS, the school and the community.

However, the care network has weaknesses that hinder an articulated work among the FHS team, other services and sectors in psychosocial care facing the demands of child mental health care, as assessed by the interest group:

It is very difficult to be able to matrix a patient directed to PSCC. It is very precarious. We do not have this direct contact. (E14)

There is no matrix from the CPSCC professionals, they do not perform HV jointly, support was never requested for any case as reported by a team professional. (06, 2.6.18, morning)

We do not have in the NASF the only way we can refer mental health to a specialist, besides the EESCA. (E2)

The professionals negatively evaluated the absence of CPSCC and NASF for support, services that could qualify care in the territory and strengthen actions of child mental health care. After all, psychosocial attention has as its main objective to expand and qualify care based on the territory, closer to the user's family, social and cultural network.

Joint work among teams is decisive for the development of mental health actions in the FHS and to promote child care, both in relation to less complex situations and to the qualification of the necessary referrals, ensuring greater user and family adherence to the care process ${ }^{(9)}$.

This corroborates with the difficulties in child mental health care identified in the evaluation process, the lack of joint work with the Child Protection Agency and 
Reference Center on Social Assistance (Conselho Tutelare Centro de Referência em Assistência Social, CRAS), since cross-sectorial work between these services could be included to compose care plans, given the social vulnerability profile identified in the study community.

We don't have much partnership and, in few times we needed it, we didn't have the answer we expected from the Child Protection Agency. (E14)

From time to time, the Child Protection Agency triggers the FHS. Very rare for the FHS to trigger the Agency. Only when something very serious is brought. The Agency triggers us, looking for some child, some family. (E11)

Few cases were referred to the CRAS, which would be a social issue, sometimes food, housing, more social. (E12)

Cross-sectorial is understood as a polysemic concept, used in the health field, which represents the way the different social sectors (education, social assistance, justice, culture, leisure, among others) with their knowledge and practices are integrated and articulated to guide and ensure cases resolution and follow-up ${ }^{(14-15)}$.

Given the fragility and lack of joint work in child mental health care, it is up to the mental health services to initiate the network construction, based on the responsibility on the case, and the subsequent involvement of all the professionals and sectors ${ }^{(8)}$.

It is understood that psychosocial attention recommends working in a cross-sectorial network, creates links with other sectors of public policy, different social segments, different services, actors and perspectives ${ }^{(14)}$. In view of the support need for childcare continuity, participants showed three forms of support and matrix for child mental health care: Specialized Team in Child and Adolescent Health (Equipe Especializada em Saúde da Criança e Adolescente, EESCA), University and Telehealth.

Thus, in the first place, the EESCA refers to a multi-professional team with training in child and adolescent health available in the studied municipality. The team is intended for the care of children and adolescents from 0 to 17 years old. They are distributed in the municipality and perform case registration with the professionals of the Primary Care teams. The participants understand that child mental health care in the FHS transcends the knowledge of the medical clinic; childcare provides articulation of knowledge for comprehensive care.

The child comes here for consultation and, if there is no resolution here with the doctor, she takes the case and takes to the matrix, which is once a month at the EESCA, which is child mental health. (E7)

In this context, the matrix support differs from the traditional care provided by a specialist, it is understood as the help of a specialized professional to a health team, expanding and qualifying the actions ${ }^{(16)}$. This integrative logic of attention is a counterpoint to the traditional logic of referral, referencing or counter-referencing of a fragmented care.

Thus, matrixing provides specialized backing of mental health care to child in the context of the FHS. It refers to a technical-pedagogical support that integrates mental health and PC for collaborative care, producing exchanges among different areas of knowledge for the construction of successful therapeutic projects.

Corroborating with this idea, another form of support identified by the interest group was the University, since it is through the activities of the teacher and students that the identification and monitoring of cases often happens.

It is very helpful to have the students, for those who are here at the health center within the neighborhood. It's not in the hospital; it's in the neighborhood that needs it. I've seen the teacher go to the house and talk, have another vision of a prepared for mental health professional, guides the family well. (E13)

We have help from the students who come here, who are from nursing who help us in cases of children's mental health. (E6)

In the evaluated context, the health service is an internship field for undergraduate Nursing students and benefits from the presence of the University for expanding health promotion and disease prevention actions, basic prerogatives of the FHS. They provide a closer relationship in the institution of the teaching-society relation, facilitating the exchange of knowledge among students, teachers and community ${ }^{(17)}$. Thus, in the context of child mental health, partnership between the University and the FHS can provide a creative and humanized care from this contact with the child and his life context.

Yet, another support for therapeutic behaviors and continuity of childcare in the FHS was identified in Telehealth.

The doctor sometimes starts right here, being a child. She started for two, one with depression, ten years old, and another child, I don't remember what the disorder is, but she has started treatment here. So, I think Telehealth is more 
effective for the doctors, because they can have a better resolution. (E5)

The doctors use it a lot, they have 1 hour for Telehealth, they even use this part of mental health in Telehealth. (E7)

The interest group evaluated Telehealth as an important tool to enroll children with mental health cases, either for clinical and therapeutic conduct, or for referral to medical specialty. Using Telehealth as a service support resource was foreseen by the Pan American Health Organization (PAHO) and by the WHO, defining the use of Information and Communication Technologies (ICTs) as strategic in cases where service provision is hindered by distance. Thus, they are alternatives for the diagnosis, treatment and prevention of diseases, as well as research and continuing education ${ }^{(18)}$.

Another resource for mental health care, especially in children, assessed by the interest group was the team meeting time at the FHS.

People are valuing the meeting more. We always consider it on the agenda. I think it's very cool, very important, because that's where I have a case from my area, so I tell everyone for their awareness, since we all go through the reception. (E12)

It arrives a lot through the CHA and then it is resolved in a team meeting, the case is passed in the team meeting and then the referral will be given. Not the solution, the proper referral, in that child mental health problem. (E13)

The multidisciplinary team meeting enables a more global and collective view of the cases of children requiring mental health care. In a context of psychosocial attention, this moment provides integration, listening, professional appreciation and case planning.

Thus, the team meeting allows for the exchange of information, communication among the professionals. It provides a participatory process in the work routine consensus construction, care projects elaboration, discovering both mental health demands as well as possibilities of care to these needs in the territory. Communication is an indispensable factor for the work in the FHS, the exercise of dialog and of exchanges in the workplace opens possibilities for a resolute work and committed to the population's needs $s^{(1,19)}$.

The space on the medical agenda was another work strategy attributed to child mental health care, important for cases of child mental health follow-up.

We have spontaneous demand consultations, the first visit most of the time when parents are very anxious is the spontaneous demand even, in the consultation of the day, for us to make a first "catch", to see what is happening. Then there are the mental health schedules, adult mental health, and child. (E2)

It used to be a unique agenda, there was pregnant woman, child, but there was no specific for mental health. And today there is the space that prevails on the agenda, providing vacancy in mental health. (E8)

The team organizes the weekly schedule of activities with space in the medical schedule for mental health monitoring. It is noteworthy that the professional care at this point of attention should be with a psychosocial approach. Attending with a psychosocial approach comprises the construction of autonomy and the overcoming of individual and specialized healing health practices; it considers subjectivity and addresses the suffering in this child's life territory ${ }^{(19)}$.

Finding strategies and arrangements to ensure care according to the appointment schedule can provide children and families with easy service access in view of their homes proximity, strengthening the family, work and social support bonds that can be important sources of recovery. Thus, in many countries PC has been evaluated as a better than specialized care considering its ease of access, lower probability of prejudice and therapeutic outcomes ${ }^{(20)}$.

Thus, the health service, faced with the need for childcare, should take the responsibility for seeking joint strategies that should be imperative for the FHS professionals involved in the care process. Pursuing comprehensive care for children with mental health demands should be a premise of all mental health services.

\section{—FINAL CONSIDERATIONS}

The research provided an opportunity to evaluate the mental health care provided to children in the context of the FHS, based on a participatory methodology that allowed us to consider the different perceptions of the interest group, formed by FHS professionals.

Thus, the participatory evaluation process developed with the professionals was important for problematizing reality, listening to different opinions of the group and driving possible changes from the formative character provided by the FGE. In this way, the interest group implication involved the service context and somehow achieved meaning for them.

By means of the analytical category of Mental Health Care for the Child, the interest group evaluated the FHS care devices, namely: home visit, care network, matrix, team meeting and medical calendar space.

Thus, it was evidenced that child mental health care happens in the activities recommended for the FHS. The Home Visit is seen as a resource to identify children with 
mental health needs in the territory, since mainly the CHAs are in contact with the home and family context. The team meeting is a valued moment, as it provides integration, listening, case discussion and care planning, and the possibility of scheduling appointments ensures continuity of follow-up. It was evaluated that these daily activities are permeated by sensitivity for psychosocial care.

However, the mental health policy does not guarantee the care network construction that must be woven by the professionals of the different services. The integration between the FHS and the territory schools was assessed as important, but timely, and the need for better articulation with other services and sectors, such as the NASF, the CPSCC and the Child Protection Agency.

Given the demands and needs of child mental health present in the territory and the difficulties and limitations of the FHS even without the CPSCC and the NASF team, several means of care support were evidenced through case matrix. They are specialized devices and knowledge such as the EESCA, available in the study municipality, the University and Telehealth as they articulate knowledge aiming at resolution and integrality care.

Thus, the study contributed to evaluate that psychosocial care has been performed in the FHS, a community-based service that allows access and continuity of the follow-up of children and families. However, a major challenge is the articulation of the PSCN, which could be a trigger for qualifying moments in the area of child mental health, raising awareness of timely care and in the territory.

The results can contribute and encourage managers to qualify the FHS professionals for mental health care, with attention to child mental health, as this is an important space for care and access in the psychosocial network.

Finally, the limitations of this study refer to the impossibility of generalizing the results considering that it is a research with a qualitative methodology; thus, the results found are related to the interest group trajectory, experience and meanings.

\section{口 REFERENCES}

1. Soalheiro N, Martins D. Atenção psicossocial e a (des)institucionalização como eixo do cuidado. In: Saúde mental para a Atenção Básica. Nina Soalheiro, organizadora. Rio de Janeiro: Fiocruz; 2017. p. 249.

2. Silva JF, Matsukura TS, Ferigato SH, Cid MFB. Adolescência e saúde mental: a perspectiva de profissionais da Atenção Básica em Saúde. Interface (Botucatu). 2019;23:e180630. doi: https://doi.org/10.1590/Interface. 180630
3. Sousa FSP, Jorge MSB. 0 retorno da centralidade do hospital psiquiátrico: retrocessos recentes na política de saúde mental. Trab Educ Saúde. 2019;17(1):e0017201. doi: https://doi.org/10.1590/1981-7746-sol00172

4. Couto MCV, Delgado PGG. Crianças e adolescentes na agenda política da saúde mental brasileira: inclusão tardia, desafios atuais. Psicol Clin. 2015;27(1):17-40. doi: https://doi.org/10.1590/0103-56652015000100002

5. Tszesnioski LC, Nobrega KBG, Lima MLLT, Facundes VLD. Building the mental health care network for children and adolescents: interventions in the territory. Ciênc Saúde Coletiva. 2015;20(2):363-70. doi: https://doi.org/10.1590/141381232015202.05082014

6. Carvalho MN, Costa EMOD, Sakai MH, Gil CRR, Leite SN. Expansão e diversificação da força de trabalho de nível superior nas Unidades Básicas de Saúde no Brasil, 2008-2013. Saúde Debate. 2016:40(109):154-62. doi: https://doi. org/10.1590/0103-1104201610912

7. Kantorski LP, Coimbra VCC, Oliveira NA, Nunes CK, Pavani FM, Sperb LCSO. Psychosocial attention of children and adolescents: interfaces with the health network by the referral and counter-referral system. Texto Contexto Enferm. 2017;26(3):e1890014. doi: https://doi.org/10.1590/0104-070720170018900 14

8. Teixeira MR, Couto MCV, Delgado PGG. Primary care and collaborative care in children and adolescents psychosocial interventions: facilitators and barriers. Ciênc Saúde Coletiva. 2017;22(6):1933-42. doi: https://doi.org/10.1590/141381232017226.06892016

9. Guba E, Lincoln, Y. Avaliação de quarta geração. Beth Honorato, tradutora. Campinas: Unicamp; 2011.

10. Kolb SM. Grounded theory and the constant comparative method: valid research strategies for educators. Jeteraps. 2012 [cited 2019 Feb 10];3(1):836. Available from: https://www.researchgate.net/publication/307632469_ Grounded_theory_and_the_constant_comparative_method_Valid_ research_strategies_for_educators

11. Ministério da Saúde (BR), Conselho Nacional de Saúde. Resolução no 466, de 12 de dezembro de 2012. Diretrizes e normas regulamentadoras de pesquisas envolvendo seres humanos. Diário Oficial da União. 2013 jun 13;150(112 Seção 1):59-62.

12. Alonso CMC, Béguin PD, Duarte FJCM. Work of community health agents in the Family Health Strategy: meta-synthesis. Rev Saúde Pública 2018;52:14. doi: https://doi.org/10.11606/s1518-8787.2018052000395

13. Chiari APG, Ferreira RC, Akerman M, Amaral JHL, Machado KM, Senna MIB. Rede intersetorial do Programa Saúde na Escola: sujeitos, percepções e práticas. Cad Saúde Pública 2018;34(5):e00104217. doi: https://doi.org/10.1590/0102$311 \times 00104217$

14. Nunes CK, Kantorski LP, Coimbra VCC. Interfaces between services and actions of the psychosocial care network for children and adolescents. Rev Gaúcha Enferm. 2016;37(3):e54858. doi: https://doi.org/10.1590/1983-1447.2016.03.54858

15. Souza AC. Estratégias de inclusão da saúde mental na atenção básica: um movimento das marés. São Paulo: Hucitec; 2015.

16. Jorge MSB, Vasconcelos MGF, Castro Junior EF, Barreto LA, Rosa LRS, Lima LL. Solvability of mental health care in the Family Health Strategy: social representation of professionals and users. Rev Esc Enferm USP. 2014;48(6):105965. doi: https://https:/doi.org/10.1590/S0080-623420140000700014 
17. Duarte MLC, Galuschka TAK. Grupo de saúde mental: um relato de experiência na extensão universitária. Rev Contexto Saúde. 2017;17(33):58-65. doi: https:// doi.org/10.21527/2176-7114.2017.33.58-65

18. Santos AF, D’Agostino M, Bouskela MS, Fernandéz A, Messina LA, Alves HJ. [An overview of telehealth initiatives in Latin America]. Rev Panam Salud Publica. 2014 [cited 2019 Mar 10];35(5/6):465-70. Portuguese. Available from: https:// www.scielosp.org/article/ssm/content/raw/?resource_ssm_path=/media/ assets/rpsp/v35n5-6/25.pdf
19. Duarte MLC, Boeck JN. 0 trabalho em equipe na enfermagem e os limites e possibilidades da estratégia saúde da família. Trab Educ Saúde, 2015;13(3):70920. doi: https://doi.org/10.1590/1981-7746-sip00054

20. Wenceslau LD, Ortega F. Mental health within primary health care and Global Mental Health: international perspectives and Brazilian context. Interface (Botucatu), 2015;19(55):1121-32. doi: https://doi.org/10.1590/1807-576220 14.1152

\section{- Corresponding author:}

Maria de Lourdes Custódio Duarte

E-mail:malulcd@yahoo.com.br

\section{Associate editors:}

Aline Marques Acosta

Cecília Helena Glanzner

Editor-in-chief:

Maria da Graça Oliveira Crossetti 